\title{
Synaptic integration and NMDA spikes in a layer 5 pyramidal neuron model
}

\author{
Matteo Farinella*, Padraig Gleeson, Daniel CT Ruidt, Angus R Silver \\ From Twentieth Annual Computational Neuroscience Meeting: CNS*2011 \\ Stockholm, Sweden. 23-28 July 2011
}

Several central neurons exhibit regenerative dendritic events, which are believed to increase the computational power of the cell [1]. NMDA receptor-mediated spikes [2] have been triggered in-vitro in thin dendrites [3] of all the main classes of cortical pyramidal neurons. They are characterized by a local depolarization of approximately 40 $50 \mathrm{mV}$ and a duration that ranges from 50 to $100 \mathrm{~ms}$, depending on the input strength [4] and the other currents recruited. This long duration suggests that the temporal integration window is significantly longer than the membrane time constant which may be important during the low firing frequencies observed in some cortical regions such as barrel cortex. Moreover, their dependence on glutamate binding suggests that they are spatially restricted to the synaptic input zone, unlike dendritic spikes mediated by $\mathrm{Na}^{+}$channels. Â These features make them particularly well suited for amplifying clustered synaptic input [5], which is one of the essential requirements for the pyramidal neuron to act as a two layer network [6]. They have also been suggested to play a key role in burst detection [7] and plasticity [8]. However, because of their distal location within fine dendritic structures, it is extremely difficult to investigate their properties experimentally. To circumvent this we have investigated the properties of synaptic integration and NMDA spike generation using a biologically detailed multi-compartmental modelling approach. We have used the L5 pyramidal cell model developed by Larkum ${ }^{3}$ and colleagues as our basic model. This was translated into NeuroML [9], making more accessible for use with modelling tools such as neuroConstruct [10]. NMDA spikes were activated with coincident synaptic input onto specific apical branches and defined with a threshold criterion. We determined the input-

\footnotetext{
* Correspondence: m.farinella@ucl.ac.uk Department of Neuroscience, Physiology and Pharmacology, University College London, London WC1E 6BT, UK
}

output relationship of different dendritic branches by quantifying the relationship between the probability of generating an NMDA spike and number of synapses activated on the branch. Consistent with previous experimental studies we found that 10-20 synapses were necessary to trigger an NMDA spike. On average, coincident NMDA spikes in 13 different apical dendritic branches were necessary to fire a somatic action potential with a 0.5 probability. However, the number of NMDA spikes required to trigger a somatic action potential was significantly reduced in the presence of background excitatory synaptic input (1500 inputs at $0.85 \mathrm{~Hz}$ ). These results suggest that NMDA spikes could have a greater contribution to integrating synaptic input in active networks than observed in acute slices where there is little ongoing synaptic activity.

\section{Acknowledgements}

This work has been funded by The Wellcome Trust.

Published: 18 July 2011

\section{References}

1. Johnston D, Magee JC, Colbert CM, Cristie BR: Active properties of neuronal dendrites. Annu Rev Neurosci 1996, 19:165-186.

2. Schiller J, Major G, Koester HJ, Schiller Y: NMDA spikes in basal dendrites of cortical pyramidal neurons. Nature 2000, 404:285-289.

3. Larkum ME, Nevian T, Sandler M, Polsky A, Schiller J: Synaptic integration in tuft dendrites of layer 5 pyramidal neurons: a new unifying principle. Science 2009, 325:756-760.

4. Major G, Polsky A, Denk W, Schiller J, Tank DW: Spatiotemporally graded NMDA spike/plateau potentials in basal dendrites of neocortical pyramidal neurons. J Neurophysiol 2008, 99:2584-2601.

5. Rhodes $P$ : The properties and implications of NMDA spikes in neocortical pyramidal cells. J Neurosci 2006, 26:6704-6715.

6. Poirazi P, Brannon, Mel BW: Pyramidal neuron as two-layer neural network. Neuron 2003, 37:989-999.

7. Polsky A, Mel B, Schiller J: Encoding and decoding bursts by NMDA spikes in basal dendrites of layer 5 pyramidal neurons. J Neurosci 2009, 29:11891-11903.

8. Gordon U, Polsky A, Schiller J: Plasticity compartments in basal dendrites of neocortical pyramidal neurons. J Neurosci 2006, 26:12717-12726.

9. Gleeson P, Crook C, Cannon RC, Hines ML, Billings GO, Farinella M, Morse TM, Davison AP, Ray S, Bhalla US, et al: NeuroML: a language for

\section{C)


describing data driven models of neurons and networks with a high degree of biological detail. PLoS Comput Biol 2010, 6:e1000815.

10. Gleeson P, Steuber V, Silver RA: neuroConstruct: a tool for modeling networks of neurons in 3D space. Neuron 2007, 54:219-235.

doi:10.1186/1471-2202-12-S1-P301

Cite this article as: Farinella et al:: Synaptic integration and NMDA

spikes in a layer 5 pyramidal neuron model. BMC Neuroscience 201112

(Suppl 1):P301.

Submit your next manuscript to BioMed Central and take full advantage of:

- Convenient online submission

- Thorough peer review

- No space constraints or color figure charges

- Immediate publication on acceptance

- Inclusion in PubMed, CAS, Scopus and Google Scholar

- Research which is freely available for redistribution

Submit your manuscript at www.biomedcentral.com/submit

() BioMed Central 